\title{
Resistance to Bean pod mottle virus in Transgenic Soybean Lines Expressing the Capsid Polyprotein
}

\author{
M. S. Srinivasa Reddy, Said A. Ghabrial, Carl T. Redmond, Randy D. Dinkins, and Glenn B. Collins
}

First, third, fourth, and fifth authors: Department of Agronomy, University of Kentucky, Lexington 40546; and second author: Department of Plant Pathology, University of Kentucky, Lexington 40546.

Accepted for publication 18 May 2001.

\begin{abstract}
Reddy, M. S. S., Ghabrial, S. A., Redmond, C. T., Dinkins, R. D., and Collins, G. B. 2001. Resistance to Bean pod mottle virus in transgenic soybean lines expressing the capsid polyprotein. Phytopathology 91:831838.

Transgenic fertile soybean plants were generated from somatic embryos of soybean (Glycine max) cv. Jack transformed via particle bombardment with the capsid polyprotein $(\mathrm{pCP})$ gene of Bean pod mottle virus (BPMV). The plant transformation vector ( $\mathrm{pHIG} / \mathrm{BPMV}-\mathrm{pCP}$ ) utilized in these experiments contained the BPMV-pCP coding sequence, an intron-containing GUS gene, and the hygromycin phosphotransferase gene. Southern blot hybridization analysis showed that 19 transgenic soybean plants selected for resistance to hygromycin contained the genes for GUS and BPMV-pCP. The progeny of five of these transgenic soybean plants (plants 137, 139, 157, 183, and 186) were characterized in detail. An additional transgenic plant (plant 200) contained the intronGUS and hygromycin resistance genes, but lacked the BPMV-pCP gene

DNA in a similar banding pattern suggesting that they were derived from a single transformation event. Western and northern blot analyses showed that the expression levels of BPMV-pCP and pCP transcript were high in these five pCP plants. Infectivity assays with detached leaves demonstrated that all five pCP plants exhibited resistance to virus infection because they accumulated lower levels of BPMV compared with plant 200 and nontransformed controls. Unlike the $\mathrm{T}_{2}$ progeny of line 183-1 that segregated with respect to the $\mathrm{pCP}$ gene and, consequently, to BPMV resistance, the $\mathrm{T}_{2}$ progeny of the homozygous line 183-2 showed little or no symptoms in response to rub-inoculation with virions of a severe strain of BPMV. Although BPMV accumulation was evident in leaves on which viruliferous beetles were allowed a 72-h inoculation access period, the upper noninoculated leaves of the $\mathrm{T}_{2}$ progeny of line 183-2 plants were symptomless and accumulated little or no virus. Because the progeny of this homozygous transgenic line exhibited systemic resistance, they could potentially be useful in generating commercial cultivars resistant to BPMV.
\end{abstract} and was used as a negative control. Southern blot hybridization analysis of the five transgenic plants showed the presence of three copies of the T-
Additional keywords: coat protein, pathogen-derived resistance.
Bean pod mottle virus (BPMV) is a member of the genus Comovirus in the family Comoviridae (15). BPMV has a bipartite positive-strand RNA genome consisting of RNA-1 and RNA-2, which are separately encapsidated in isometric particles $28 \mathrm{~nm}$ in diameter. Both genomic RNAs are polyadenylated and have a small basic protein, viral genome-linked protein ( $\mathrm{VPg}$ ), covalently linked to their $5^{\prime}$ termini. Like other comoviruses, the BPMV genome is expressed via the synthesis and subsequent cleavage of large polyprotein precursors (19). The complete nucleotide sequences of the two genomic RNAs of BPMV strain KY-G7 have been reported $(7,21)$. BPMV RNA-1 codes for five mature proteins required for replication (from $5^{\prime}$ to $3^{\prime}$, a protease cofactor $[32 \mathrm{~K}]$, a putative helicase $[58 \mathrm{~K}]$, a $\mathrm{VPg}$, a protease [24K], and a putative RNA-dependent RNA polymerase [87K]), whereas RNA2 codes for a putative cell-to-cell movement protein and the two coat proteins (CPs) $(7,21)$.

BPMV is widespread in the major soybean-growing areas in many of the southern and southeastern states $(13,16,34,39)$. Over the past 2 to 3 years, it has become an increasingly serious production problem in the North Central and Northern Great Plains states (J. Hill, personal communication). BPMV is efficiently transmitted in nature, within and between soybean fields, by several species of chrysomelid beetles $(12,16,32)$. The deleterious effects of BPMV infection are not limited to reductions in seed

Corresponding author: S. A. Ghabrial; E-mail address: saghab00@pop.uky.edu Reprint requests to G. B. Collins; E-mail address: gcollins@ pop.uky.edu

Publication no. P-2001-0702-01R

(C) 2001 The American Phytopathological Society yield, but extend to seed quality because BPMV has been reported to predispose soybeans to Phomopsis spp. seed infection (40), a major cause of poor seed quality in soybean (38). Furthermore, BPMV interacts synergistically with Soybean mosaic virus, resulting in more severe yield losses than caused by either virus alone $(1,5,33)$.

Disease management through genetic resistance is not possible at present because no soybean cultivars with resistance to BPMV are commercially available. The concept of pathogen-derived resistance (PDR), first proposed in 1985 (36), has been successfully utilized over the past 15 years to confer resistance against viruses in many crop plants. PDR involves the expression of viral genes in a host plant and the subsequent disruption of the essential pathogenic processes of challenge virus, thus conferring resistance. PDR has been attained by expressing various forms of the viral $\mathrm{CP}$, replicase, protease, and movement protein genes. PDRmediated protection phenotypes range from a delay in symptom development, reduced symptoms, and virion accumulation to apparent immunity $(3,4,10,20,26)$. The diversity in PDR phenotypes suggests that there are multiple mechanisms underlying the attained protection. The first example of PDR reported was in transgenic tobacco that accumulated CP of Tobacco mosaic virus, and the significant resistance achieved was termed CP-mediated resistance (4). Protection against viruses with two CPs (like comoviruses) could be achieved by expressing the capsid polyprotein (pCP; referred to in earlier studies as the precursor to the two CPs), or by expressing both the individual CP genes $(8,28,29)$.

An earlier report showed that it is possible to obtain resistance to BPMV by expressing the pCP in transgenic soybean plants (8). However, the transgene utilized in that study was not stable, 
resulting in its loss in advanced generations and a subsequent loss of resistance (S. A. Ghabrial, unpublished data). The PDR against BPMV, reported in the present study, was generated by transformation of soybean with the BPMV-pCP gene via particle bombardment of somatic embryo cultures. Resistance to BPMV was demonstrated in the $T_{2}$ progeny of transgenic lines in plants inoculated mechanically and with viruliferous bean leaf beetles.

\section{MATERIALS AND METHODS}

Construction of the binary plasmid pHIG/BPMV-pCP. The 1.9-kbp EcoRI/ClaI fragment with the BPMV-pCP gene was removed from pMON1900 (8), blunt-ended with the $\mathrm{T}_{4}$ DNA polymerase, and inserted into pBSFMA, a Bluescript-based plasmid containing a duplicated Figwort mosaic virus (FMV) $35 \mathrm{~S}$ promoter (22) and rubisco small subunit gene (rbcS) terminator. The FMV $35 S^{2}$-BPMV-pCP-rbcS 3 ' construct was ligated into the binary vector pHIG (44) to generate the recombinant plasmid pHIG/BPMV-pCP (Fig. 1).

Tissue culture and transformation. Somatic embryogenic cultures were initiated by plating immature (5 to $7 \mathrm{~mm}$ ) zygotic embryogenic cotyledons (cv. Jack) on initiation media (Murashige and Skoog [MS]-based medium [27] containing [per liter] $40 \mathrm{mg}$ of 2,4-D, $20 \mathrm{~g}$ of sucrose, and $2 \mathrm{~g}$ of phytagel, $\mathrm{pH} 7.0$ ), and maintained in a culture room $\left(23: 1 \mathrm{~h}\right.$ light/dark at $\left.23^{\circ} \mathrm{C}\right)$ as detailed by Trick et al. (42). Embryos were transferred to proliferation media (MS-based medium containing, per liter, $20 \mathrm{mg}$ of 2,4-D, $20 \mathrm{~g}$ of sucrose, and $2 \mathrm{~g}$ of phytagel, $\mathrm{pH}$ 5.8) for embryogenic proliferation of somatic embryos, with transfers made to fresh media every 21 to 24 days. Green embryos from raspberry-shaped clumps were selected for transformation by a dissecting microscope (Zeiss SV6; Carl Zeiss, Oberkochen, Germany). Selected material was placed in the center of a moist filter paper in sterile petri plates for $2 \mathrm{~h}$ (approximately 100 to $150 \mathrm{mg}$ of somatic embryos per plate) and dried in a laminar flow hood for $15 \mathrm{~min}$ prior to bombardment. Transformation was carried out via particle bombardment with a gene gun (Dupont PDS1000; Bio-Rad Laboratories, Hercules, CA) by gold/DNA microprojectile preparations. Modifications to the standard protocol (42) included targeting each culture with a single shot (for nine shots, $25 \mu \mathrm{g}$ of DNA was used to coat $7.5 \mathrm{mg}$ of $0.6 \mu \mathrm{m}$ gold). Cultures were bombarded by $1,550-\mathrm{lb} / \mathrm{in}^{2}$ rupture disks (Bio-Rad) coupled with a focusing device (41) at $11.0 \mathrm{~cm}$ from rupture disk to target tissue.

Immediately after bombardment, embryogenic cultures were placed on proliferation media without any selective agent for 7 days. Selection of transformed material was done by transferring embryo cultures to proliferation media augmented with $15 \mathrm{mg} / \mathrm{liter}$ of hygromycin, pH 5.8, (Sigma Chemical, St. Louis) for 14 days, then transferred to proliferation media with $30 \mathrm{mg} / \mathrm{liter}$ of hygromycin for 5 to 6 months, including transfer to fresh media every 4 weeks. During these transfers, some of the putative transgenic embryos were fractured. Such broken embryos could have given rise to one or more clones derived from a single transformation event. Surviving dark green clumps of embryogenic cultures were transferred onto maturation media (MS-based medium containing per liter, $60 \mathrm{~g}$ of maltose, $2 \mathrm{~g}$ of phytagel, and $0.5 \mathrm{~g}$ of activated charcoal, $\mathrm{pH}$ 5.8) for 21 days. Final maturation was obtained by transferring individual embryos onto maturation media until embryos had grown to $1.0 \mathrm{~cm}$ in length with visible cotyledons. Groups of six to eight embryos were desiccated in plastic petri plates sealed with Parafilm for 3 to 7 days. Embryos were removed as they became creamy white in color and were transferred to germination media (MS-based medium containing $30 \mathrm{~g}$ per liter of sucrose and $2 \mathrm{~g}$ of phytagel, $\mathrm{pH}$ 5.8). Most embryos began to form shoots and roots in 14 to 21 days, with some embryos requiring up to 8 weeks. These plantlets were transferred to Phytatrays (Sigma Chemical) containing half-strength B5 medium (11) for 14 days before being planted into artificial soil (ProMix BX, Premier Horticulture Inc., Red Hill, PA) and placed in humidity domes for acclimatization and subsequent transfer to the greenhouse.

Southern blot hybridization analysis. Genomic DNA was isolated from young leaves of soybean by homogenizing $100 \mathrm{mg}$ of leaf tissue in a $1.5-\mathrm{ml}$ microfuge tube containing $500 \mu \mathrm{l}$ of extraction buffer (100 mM Tris-HCl, pH 8.0, 20 mM EDTA, $0.5 \mathrm{M}$ $\mathrm{NaCl}, 0.5 \%$ [wt/vol] sodium dodecyl sulfate [SDS], and $0.5 \%$ [vol/vol] $\beta$-mercaptoethanol). The homogenate was extracted with $500 \mu \mathrm{l}$ of a phenol/chloroform/isoamyl alcohol mixture (25:24:1) and centrifuged at $12,000 \times g$ for $5 \mathrm{~min}$. The aqueous phase was collected, mixed with $1 \mu \mathrm{l}$ of $10 \mathrm{mg} / \mathrm{ml}$ of RNase A, and incubated at room temperature for $20 \mathrm{~min}$. The samples were re-extracted with an equal volume of phenol/chloroform/isoamyl alcohol (25:24:1), followed by two re-extractions with chloroform/isoamyl alcohol (24:1). DNA was precipitated by adding 2.5 volumes of ethanol and spooled out with a sterile glass Pasteur pipette. The spooled DNA was washed with $70 \%$ ethanol, dried, and resuspended in $100 \mu \mathrm{l}$ of sterile water.

Five micrograms of DNA from each plant was digested overnight with HindIII or EcoRI, fractionated in $0.8 \%$ agarose gels, and blotted onto Zetaprobe membrane (Bio-Rad). Hybridization was done overnight at $42^{\circ} \mathrm{C}$ in a hybridization solution containing $50 \%$ formamide, $0.12 \mathrm{M} \mathrm{Na}_{2} \mathrm{HPO} 4,0.25 \mathrm{M} \mathrm{NaCl}$, and $1 \mathrm{mM}$ EDTA with either a 2.1-kb HindIII/EcoRI GUS-specific fragment or a 0.35-kb HindIII BPMV-pCP gene-specific fragment random prime labeled with $\left[\alpha^{32} \mathrm{P}\right] \mathrm{dCTP}$ (Prime-It II Random Primer Labeling Kit; Stratagene, La Jolla, CA) as a probe. The membrane was washed three times at room temperature in $0.1 \times \operatorname{SSC}(1 \times$

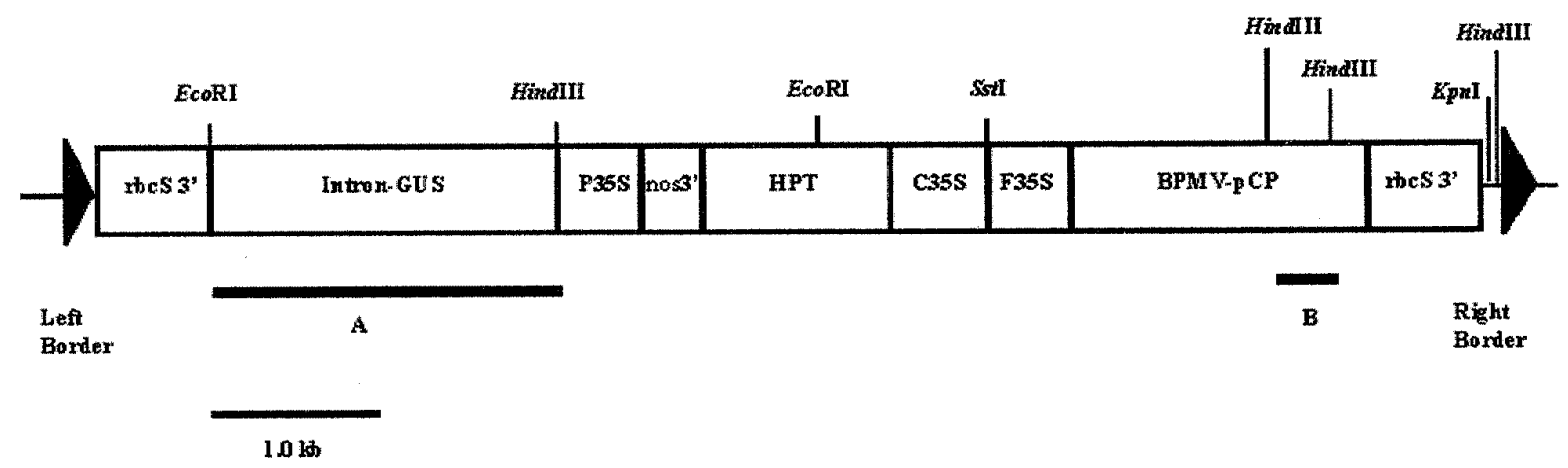

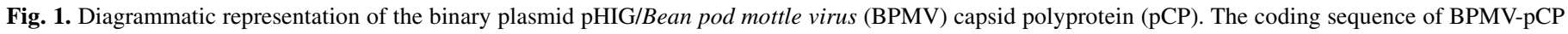

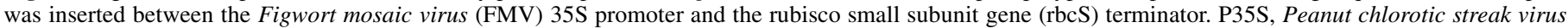

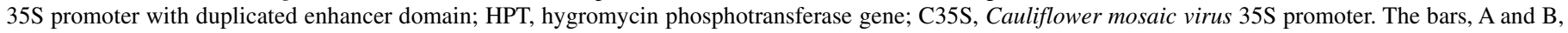

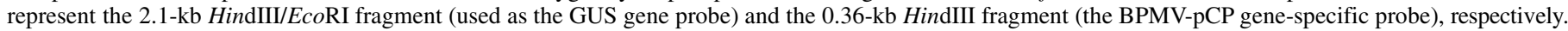
The recombinant binary vector contains two EcoRI sites and four HindIII sites. The horizontal line at bottom (1.0 kb) indicates the size scale for the vector. 
SSC is $0.15 \mathrm{M} \mathrm{NaCl}$ plus $0.015 \mathrm{M}$ sodium citrate) and $0.1 \%$ SDS and exposed in a phosphorImager cassette (Molecular Dynamics, Sunnyvale, CA). The intensity of hybridized DNA bands was estimated using the ImageQuant software program (Molecular Dynamics).

Northern blot analysis. Total RNA was isolated from $100 \mathrm{mg}$ of young leaf tissue using the Trizol reagent as suggested by the supplier (Gibco-BRL, Rockville, MD). Ten micrograms of total RNA was fractionated in $1.0 \%$ formaldehyde-agarose gels and transferred onto a Zetaprobe membrane. Conditions for hybridization and washing of membranes were as described for Southern blot hybridization analysis.

Immunoblot analysis. Leaf samples from transgenic plants were homogenized in $10 \mathrm{mM}$ sodium phosphate buffer, $\mathrm{pH} \mathrm{6.8,}$ containing $1 \mathrm{mM}$ phenylmethylsulfonyl fluoride. The homogenate was centrifuged at $12,000 \times g$ for $10 \mathrm{~min}$, and the supernatant was collected. The protein concentration was estimated with a protein assay (Bio-Rad). For immunoblot analysis, $15 \mu \mathrm{g}$ of protein was analyzed by SDS-polyacrylamide gel electrophoresis in $12 \%$ polyacrylamide gels according to the method of Laemmli (18). Proteins were electroblotted onto a nitrocellulose membrane in $25 \mathrm{mM}$ Tris, $192 \mathrm{mM}$ glycine, and $20 \%$ methanol (pH 8.2). The membrane was blocked for $2 \mathrm{~h}$ in $5 \%$ dry milk in Tris-buffered saline containing $0.05 \%$ Tween 20 and incubated with an antiserum to BPMV (14) in the same solution. Antigen-antibody complexes were visualized with horseradish peroxidase-conjugated goat antirabbit immunoglobulin $\mathrm{G}$ and an enhanced chemiluminescence kit (Amersham Pharmacia Biotech, Buckinghamshire, England).

GUS staining. Plant tissue (leaf disks or flowers) was placed in vials containing the GUS assay buffer $(50 \mathrm{mM}$ sodium phosphate, $500 \mathrm{mM}$ potassium ferricyanide, $500 \mathrm{mM}$ potassium ferrocyanide, $10 \mathrm{mM}$ EDTA, $1 \mathrm{mM}$ X-gluc [5-bromo-4-chloro-3-indolyl- $\beta$-Dglucuronide], and $0.05 \%$ Triton $\mathrm{X}-100, \mathrm{pH} 7.0$ ) and incubated overnight at $37^{\circ} \mathrm{C}$ with gentle agitation (17). The assay buffer was decanted, and the seedlings were bleached in $95 \% \mathrm{EtOH}$ to remove the chlorophyll.

Accumulation of BPMV-pCP in transgenic soybeans and evaluation of resistance to BPMV infection. To quantify the accumulation of BPMV-pCP, four leaf disks were collected from the leaves of BPMV-pCP transgenic soybean plants and homogenized in $500 \mu \mathrm{l}$ of phosphate-buffered saline (PBS)-polyvinylpyrrolidone (PVP)-Tween buffer ( $\mathrm{pH}$ 7.4). Serial 10-fold dilutions were made, and the BPMV-pCP levels were estimated by a double-antibody sandwich, enzyme-linked immunosorbent assay (ELISA) as described by Ghabrial and Schultz (14). Leaf extract dilutions, which produce ELISA absorbance values that fall within the linear phase of the standard sigmoid curve generated with purified virus concentration versus absorbency readings, were used.

The resistance of the primary transformants was evaluated with a detached leaf assay. Briefly, young fully expanded trifoliolate leaves from the BPMV-pCP soybeans were collected. Two of the Carborundum-dusted leaflets from each trifoliolate leaf were rubinoculated with $10 \mu \mathrm{g} / \mathrm{ml}(100 \mu \mathrm{l}$ per leaflet) of purified BPMV virions resuspended in $0.05 \mathrm{M}$ potassium phosphate buffer, $\mathrm{pH} 7.0$ (strain KY-G7, a relatively mild strain, was used). The third leaflet was mock inoculated with $0.05 \mathrm{M}$ potassium phosphate buffer, $\mathrm{pH}$ 7.0. The inoculated trifoliolate leaves were placed in magenta boxes (Sigma Chemical) containing sterile cotton moistened with $0.02 \%$ of Peter's professional 20-20-20 fertilizer (Scotts Sierra Horticultural Products Co., Marysville, $\mathrm{OH})$. The leaves were incubated at $26^{\circ} \mathrm{C}$ in a growth room for 7 days. Four leaf disks were sampled from each leaflet, homogenized in $500 \mu \mathrm{l}$ of PBSPVP-Tween 20, and tested by ELISA as described previously.

Seedlings, at V2 stage (9), representing the $\mathrm{T}_{2}$ progeny of transgenic soybean lines were assessed for virus resistance by rubinoculation with purified virions $(10 \mu \mathrm{g} / \mathrm{ml})$ or with viruliferous bean leaf beetles that were allowed to feed on the test transgenic seedlings for $72 \mathrm{~h}$. A severe BPMV strain, Hopkins, was used in these inoculation experiments.

\section{RESULTS AND DISCUSSION}

Integration of the BPMV-pCP gene in soybean. In the first transformation experiment, 14 embryos that were green, and thus resistant to hygromycin after a 5 to 7 month selection, were removed for maturation and germination. Twelve of these embryos

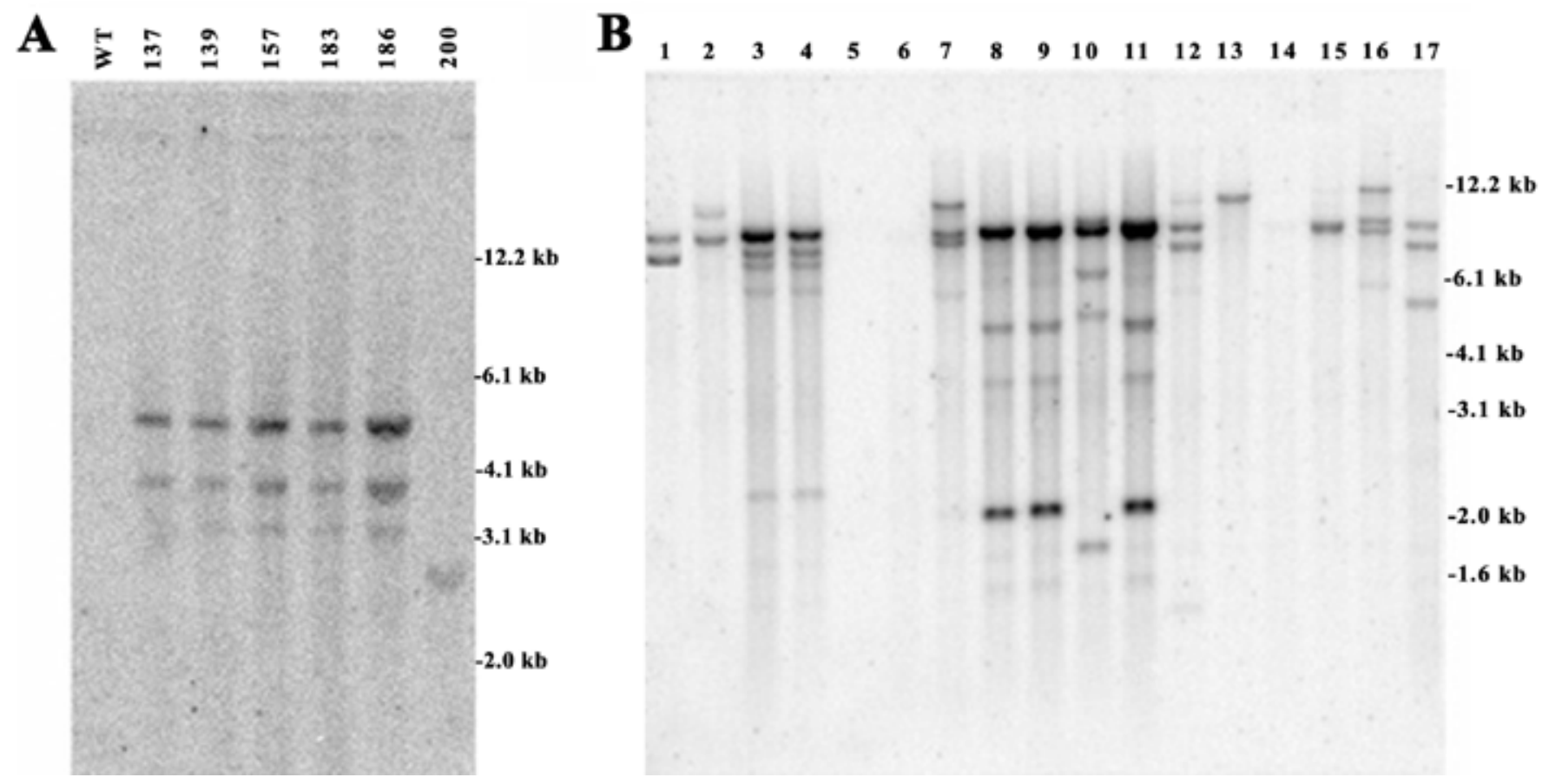

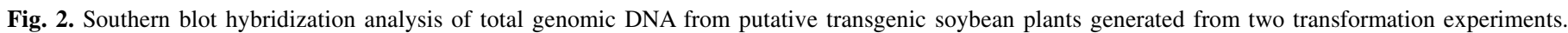

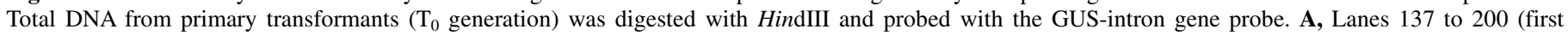

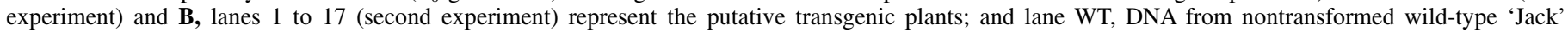
soybean. The positions of the size markers in the 1-kb DNA ladder (Life Technologies, Rockville, MD) are indicated to the right. 
developed shoots and roots and 10 of these were taken to the greenhouse, whereas the other two died in the humidity dome. Likewise, 22 hygromycin-resistant transgenic plants were also recovered in a second transformation experiment. Total genomic DNA was isolated from all 32 putative transgenic plants generated in the two experiments. Southern blot hybridization analysis of HindIII-digested DNA with the GUS gene probe indicated that the GUS gene was present in 6 of 10 plants from experiment 1 (Fig. 2A) and in 14 of 22 plants from experiment 2 (Fig. 2B). The hybridization profiles depicted in Figure 2A and B suggest that the transgenic plants recovered in experiments 1 and 2 represent two and eight independent integration events, respectively. The finding that some of the hygromycin-resistant plants lacked the transgenes indicates that selection in the presence of hygromycin was not very stringent.

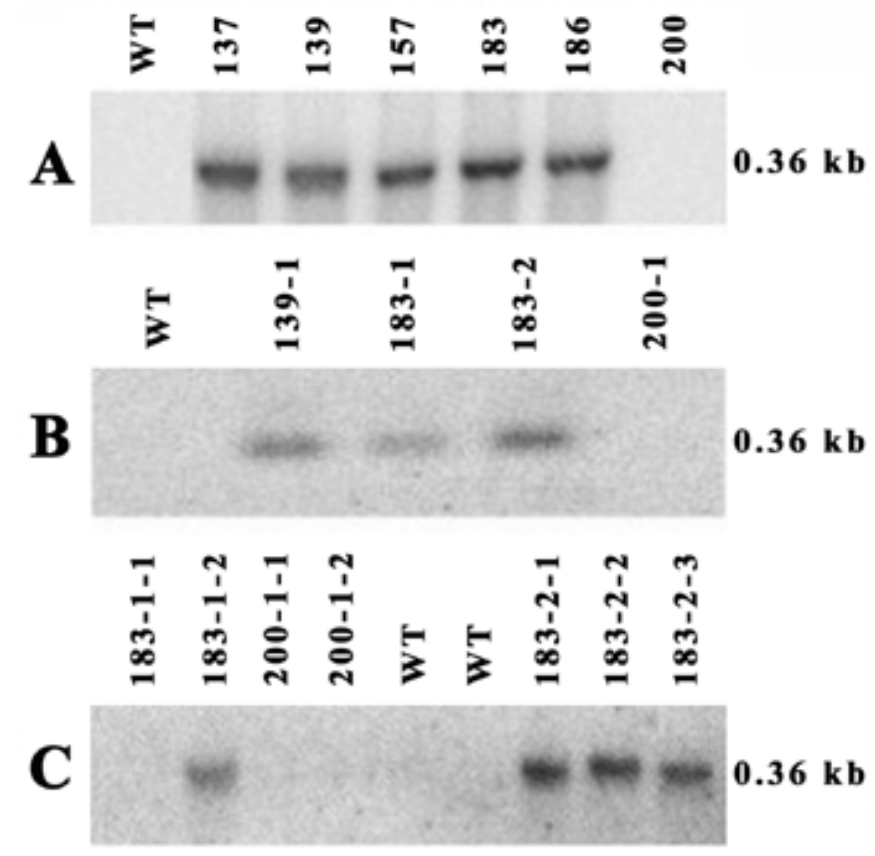

Fig. 3. Southern blot hybridization analysis of DNA from primary transformants and progeny. DNA was digested with HindIII and hybridized with the 0.36-kb HindIII fragment of the Bean pod mottle virus (BPMV) capsid polyprotein (pCP) gene as a probe. A, The Southern blot shown in Figure 2A was reprobed with the BPMV-pCP gene probe after the GUS gene probe was stripped, lanes WT, nontransformed wild-type 'Jack' soybean; 137, 139, 157, 183,186 , and 200 are the primary tansformants. B, $\mathrm{T}_{1}$ generation: lanes 139-1 and 200-1 were the lone progeny lines of 139 and 200, respectively, and 183-1 and 183-2 were the two progeny lines obtained from 183. C, $\mathrm{T}_{2}$ generation: lanes 183-1-1, 183-1-2, 200-1-1, 200-1-2, 183-2-1, 183-2-2, and 183-2-3 are representative $\mathrm{T}_{2}$ progeny of lines 183-1, 200-1, and 183-2.

$\mathbf{A}$

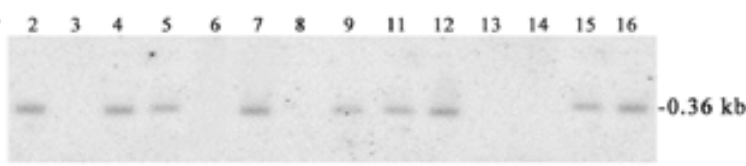

B

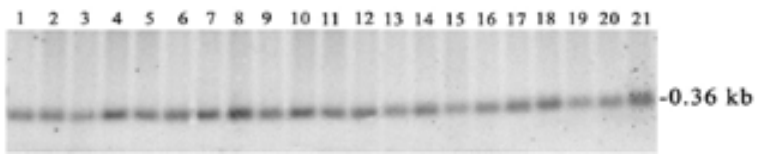

Fig. 4. Southern blot hybridization analysis of DNA from $T_{2}$ progeny of lines 183-1 and 183-2. Total DNA from the $\mathrm{T}_{2}$ progeny of $\mathbf{A}$, line 183-1 (plants 2 to 16 , and $\mathbf{B}$, line $183-2$ (plants 1 to 21 , panel $\mathbf{B}$ ) was digested with HindIII and probed with the Bean pod mottle virus capsid polyprotein $(\mathrm{pCP})$ gene probe. Note that the progeny of line 183-1, but not that of line 183-2, segregated for the $\mathrm{pCP}$ transgene.
The results of the Southern blot hybridization analysis shown in Figure 2A revealed the presence of three copies of the GUS gene in each of five transgenic plants $(137,139,157,183$, and 186), whereas there was only one copy detected in plant 200 . When the
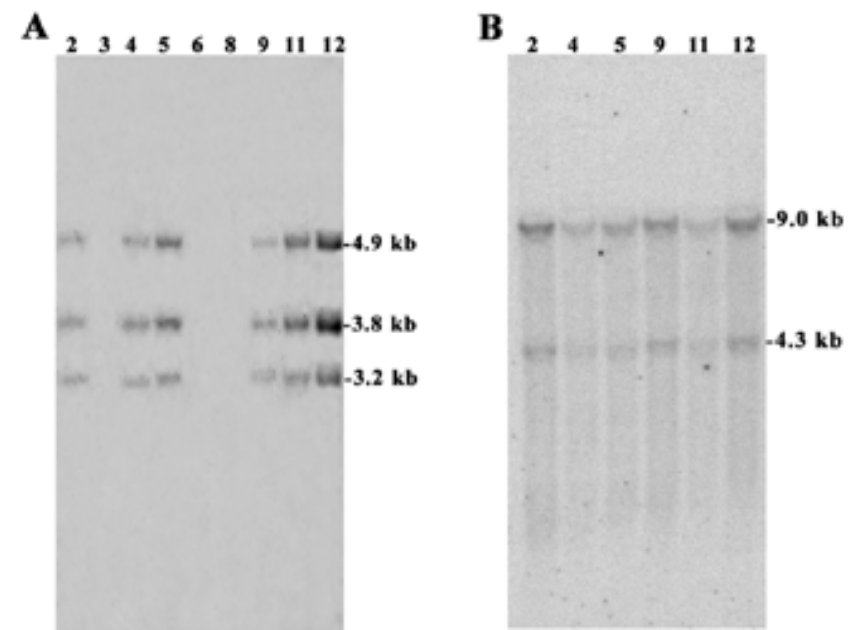

Fig. 5. Southern blot hybridization analysis of DNA from $T_{2}$ progeny of line 183-1. A, Total DNA from the $T_{2}$ progeny of line 183-1 (plants 2 to 12 ) was digested with HindIII and probed with the GUS-intron gene probe, or $\mathbf{B}$, digested with EcoRI and probed with the Bean pod mottle virus capsid polyprotein (pCP) gene probe. Note that the $\mathrm{T}_{2}$ progeny of line $183-1$ is segregating for the $\mathrm{pCP}$ gene and that the transgenic progeny maintained the three copies of T-DNA intact.

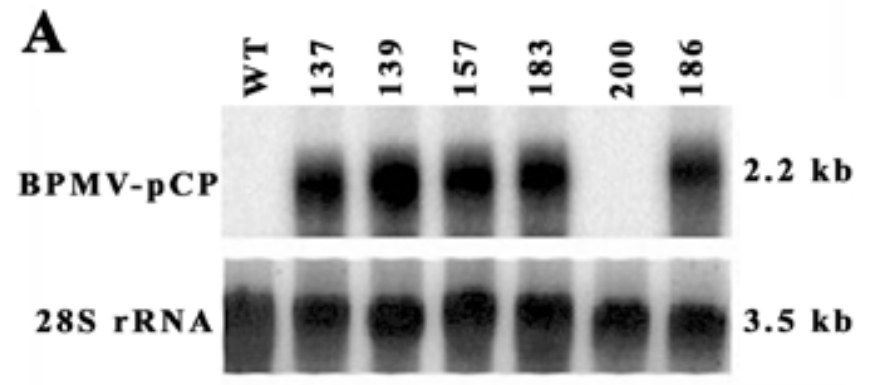

B
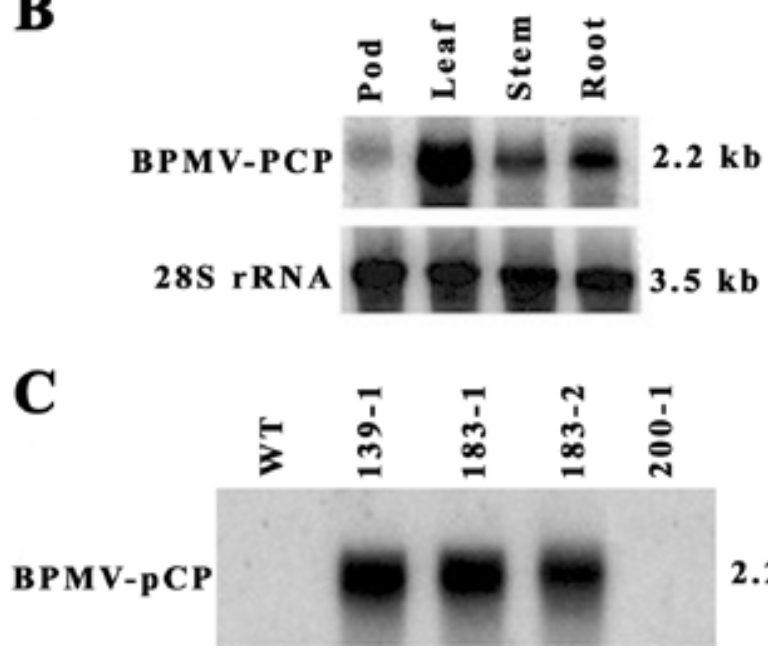

$2.2 \mathrm{~kb}$

Fig. 6. Northern blot hybridization analysis of $T_{0}$ and $T_{1}$ transgenic soybean plants. Blots of total RNA from $\mathbf{A}$, leaves of the primary transformants 137 to 200 , different tissues from $\mathbf{B}$, the $\mathrm{T}_{0}$ plant 183 , and from $\mathbf{C}$, leaves of $\mathrm{T}_{1}$ progeny of 139 lines (139-1), 183 (183-1 and 183-2), and 200 (200-1) were hybridized with the 0.36-kb Bean pod mottle virus (BPMV) capsid polyprotein $(\mathrm{pCP})$ gene-specific fragment or with a $28 \mathrm{~S}$ rRNA gene-specific probe. Lane WT, nontransformed wild-type 'Jack' soybean. 
GUS gene probe was stripped from the HindIII-digested DNA blot and the blot was reprobed with the BPMV-pCP gene probe, only five of the six GUS-positive transgenic plants from experiment 1 contained the BPMV-pCP gene (Fig. 3A). The five transgenic plants containing three copies of T-DNA were probably from the same integration event, whereas plant 200 likely had an incomplete copy of T-DNA (i.e., lacking the BPMV-pCP gene) and was from a different transformation event. All 14 GUS-positive transgenic plants recovered in experiment 2 contained the pCP gene when the GUS gene probe was stripped and the blot (Fig. 2B) was reprobed with the pCP gene probe (data not shown). Further analysis of the transgenic plants was confined to advanced generations (i.e., $\mathrm{T}_{1}$ and $\mathrm{T}_{2}$ progeny) of plants recovered in experiment 1.

Southern blot hybridization analysis showed that the $\mathrm{T}_{1}$ progeny of plant 139 (line 139-1) and plant 183 (lines 183-1 and 183-2) inherited the BPMV-pCP gene (Fig. 3B). Likewise, the $\mathrm{T}_{2}$ progeny of lines 183-1 and 183-2 inherited the BPMV-pCP gene (Fig. 3C). Furthermore, Southern blot hybridization analysis of $21 \mathrm{~T}_{2}$ progeny of line 183-2 showed that all the $\mathrm{T}_{2}$ progeny inherited the $\mathrm{pCP}$ gene (Fig. 4B). The $\mathrm{T}_{2}$ progeny of line 183-1, on the other hand, segregated for the transgene (Fig. 4A). Of a total of $19 \mathrm{~T}_{2}$ progeny tested, 12 were positive for the transgenes. Although the ratio of positive to negative plants was lower than the expected 3:1 ratio, it could be explained based on the small size of the population examined. Altogether, the results clearly support the conclusion that line 183-2 is homozygous, whereas line 183-1 is hemizygous. Further analysis of the $\mathrm{T}_{2}$ progeny of line 183-1 revealed that the three copies of T-DNA are linked because they were inherited intact even in the $T_{2}$ generation (Fig. 5A). Moreover, Southern blot hybridization analysis of EcoRI-digested genomic DNA with the BPMV-pCP gene probe suggest that two of the T-DNA copies were inserted side by side in the genomic DNA in a tail-to-tail arrangement. The approximate 9.0-kb EcoRI fragment shown in Figure 5B could be accounted for by the tail-to-tail orientation of two of the T-DNA copies, whereas the 4.3-kb EcoRI fragment is predicted to originate from the third copy, which is probably closely located (Fig. 1 for estimating the size of the resultant EcoRI fragments).

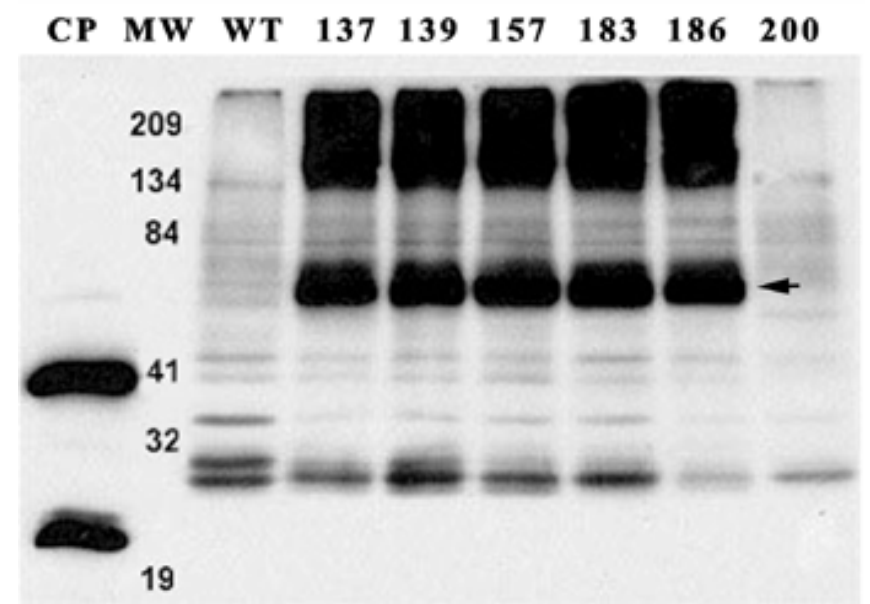

Fig. 7. Immunoblot analysis of $\mathrm{T}_{0}$ transgenic soybean plants. Total soluble proteins isolated from leaves of the primary transformants (137 to 200) were subjected to sodium dodecyl sulfate polyacrylamide gel electrophoresis, and the separated proteins were transferred to a nitrocellulose membrane and probed with an antiserum to Bean pod mottle virus (BPMV). Lane CP, purified BPMV virions containing the large $(41 \mathrm{kDa})$ and small $(22 \mathrm{kDa})$ coat protein subunits; MW, Kaleidoscope prestained standards (BioRad Laboratories, Hercules, CA); WT, protein from nontransformed wild-type 'Jack' soybean; and 137 to 200, protein from the indicated primary transformants. The position of the $63-\mathrm{kDa}$ capsid polyprotein $(\mathrm{pCP})$ is indicated by an arrow. The high molecular weight signal observed for pCP transgenic plants (lanes 137, 139, 157, 183, and 186) is probably due to aggregation of $\mathrm{pCP}$.
The instability of the BPMV-pCP transgene reported by Di et al. (8) could be explained if some of the $\mathrm{T}_{0}$ transgenic lines derived from Agrobacterium-mediated transformation of cotyledonary nodes were chimeric. Problems associated with transgenic chimeras from transformation of meristematic tissues have been previously described $(6,25,45)$. In addition, Agrobacterium-mediated transformation of soybean is not routine due to the recalcitrance of soybean to infection by Agrobacterium tumefaciens $(42,44)$. Particle bombardment of soybean shoot apical meristems $(2,24)$ or embryogenic suspension cultures $(23,30,31)$ has been successfully used to circumvent the problems posed by Agrobacteriummediated transformation. However, transgenic soybean plants derived by particle bombardment of shoot apical meristems also can be chimeric (6). Somatic embryogenic cultures offer advantages over other methods for soybean transformation. Secondary somatic embryos appear to be derived from single cells or from a few epidermal cells of primary embryos, thereby reducing the chances of chimerism. However, there is a possibility of obtaining multiple transgenic lines derived from the same initial transformation event. Recent developments have increased the efficiency of the embryogenic system and decreased the time needed for initiation of somatic embryos and regeneration $(35,37,43)$. Hence, in the present study, somatic embryos were used as the explants to generate transgenic soybean lines.

TABLE 1. Double antibody sandwich, enzyme-linked immunosorbent assay (ELISA) of detached leaves from transgenic $\mathrm{T}_{0}$ soybean plants previously inoculated with Bean pod mottle virus (BPMV) ${ }^{\mathrm{a}}$

\begin{tabular}{lcc}
\hline & \multicolumn{2}{c}{ ELISA absorbance values $\left(A_{405 \mathrm{~nm}}\right)$} \\
\cline { 2 - 3 } Sample & Mock-inoculated & BPMV-inoculated $^{\mathrm{b}}$ \\
\hline T-137 & 0.321 & 0.484 \\
T-139 & 0.329 & 0.411 \\
T-157 & 0.275 & 0.397 \\
T-183 & 0.329 & 0.370 \\
T-186 & 0.237 & 0.386 \\
T-200 & 0.011 & 0.756 \\
'Jack' & 0.010 & 0.807 \\
Purified BPMV & & \\
75 ng/ml & 0.226 & $\ldots$ \\
150 ng/ml & 0.422 & $\ldots$ \\
\hline
\end{tabular}

a Values are averages of two replicates of each of two leaflets per treatment.

b Carborundum-dusted leaflets were rub-inoculated with purified BPMV virions $(10 \mu \mathrm{g} / \mathrm{ml} ; 100 \mu \mathrm{l}$ per leaflet). Two leaflets of each trifoliolate leaf were virus-inoculated and the third leaflet was mock-inoculated with inoculation buffer (0.05 M potassium phosphate buffer, $\mathrm{pH} 7.0$ ).

TABLE 2. Reactions of $\mathrm{T}_{2}$ transgenic plants to inoculation with Bean pod mottle virus (BPMV) as evaluated by symptoms development and double antibody sandwich, enzyme-linked immunosorbent assay (ELISA) ${ }^{\mathrm{a}}$

\begin{tabular}{lccc}
\hline $\begin{array}{l}\text { Progeny } \\
(+/- \text { pCP gene })^{\mathrm{b}}\end{array}$ & Symptoms $^{\mathrm{c}}$ & $\begin{array}{c}\text { ELISA values } \\
A_{405 \mathrm{~nm}}\end{array}$ & $\begin{array}{c}\text { Southern blot } \\
\text { analysis }^{\mathrm{d}}\end{array}$ \\
\hline $183-1-1(-)$ & $\ldots$ & 1.277 & Lane 183-1-1 \\
$183-1-2(+)$ & Figure 8C & 0.884 & Lane 183-1-2 \\
$183-2-1(+)$ & $\ldots$ & 0.164 & Lane 183-2-1 \\
$183-2-2(+)$ & Figure 8D & 0.145 & Lane 183-2-2 \\
$183-2-3(+)$ & $\ldots$ & 0.156 & Lane 183-2-3 \\
$200-1-1(+)$ & Figure 8B & 1.325 & Lane 200-1-1 \\
$200-1-2(+)$ & $\ldots$ & 1.891 & Lane 200-1-2 \\
Jack-1 $(-)$ & Figure 8A & 1.174 & Lane WT \\
Jack-2 $(-)$ & $\ldots$ & 1.291 & $\ldots$ \\
\hline
\end{tabular}

a ELISA values for noninoculated transgenic plants were in the range of 0.1 to 0.3 . ELISA values for noninoculated controls ('Jack' and $\mathrm{T}_{2}$ progeny of line 200-1, nontransformed and vector-transformed controls, respectively) were in the range of 0.010 to 0.015 .

$\mathrm{b}(-)$ or $(+)$ indicates plants lacking or containing the capsid polyprotein $(\mathrm{pCP})$ gene, respectively, as determined by Southern blot hybridization analysis.

c The symptoms developed in response to BPMV inoculation are shown in Figure 8 as indicated.

$\mathrm{d}$ The pertinent lanes from the Southern blot shown in Figure $3 \mathrm{C}$ are indicated. 
Partial sterility in the transgenic soybeans. Primary transformants 137, 139, 157, 183, 186, and 200 exhibited varying degrees of fertility, but in all cases, the majority of flowers aborted or failed to set seed. Most of the remaining flowers produced psuedopods that were approximately $1 \mathrm{~cm}$ in length and without any seed. However, we were able to recover two, three, and one seed from plants 139, 183, and 200, respectively. Upon germination, progeny of plant $183(183-1,183-2)$ and of plants 139 and 200 (139-1 and 200-1, respectively) were recovered. The progeny of plants 139, 183, and 200 set normal pods. These sterility problems may be related to the long period in tissue culture (6 to 8 months), but are apparently evident only in the initial generation. No longterm phenotypic changes or heritable fertility decreases have been noted in subsequent generations.

Expression of BPMV-pCP in the transgenic plants. Using the GUS gene probe, northern blot hybridization analysis of total RNA isolated from $\mathrm{T}_{0}$ plants $137,139,157,183,186$, and 200 revealed the presence of the GUS transcript in all plants (data not shown). GUS activity was high in these plants, revealed by the intense blue of the stained leaves (data not shown). Northern blot hybridization analysis with the BPMV-pCP gene probe (Fig. 6A) showed that the BPMV-pCP transcript was present at high levels in all plants except T-200, which was consistent with the Southern blot hybridization data. Moreover, the transcript levels of the BPMV-pCP gene in these plants were similar, most likely because they were all derived from the same integration event. Further analyses with total RNA isolated from pod, leaf, stem, and root from plant 183 revealed that the BPMV-pCP transcript levels were highest in leaves compared with roots, stems, and pods, respectively (Fig. 6B). This pattern of differential expression was evident in tissues from plants 157 and 186 (data not shown). Northern blot analysis of $\mathrm{T}_{1}$ progeny of lines 139-1, 183-1, 183-2, and 200-1 revealed that the BPMV-pCP transcript levels were also high, therefore, comparable to those noted in the $\mathrm{T}_{0}$ generation (Fig. 6C).
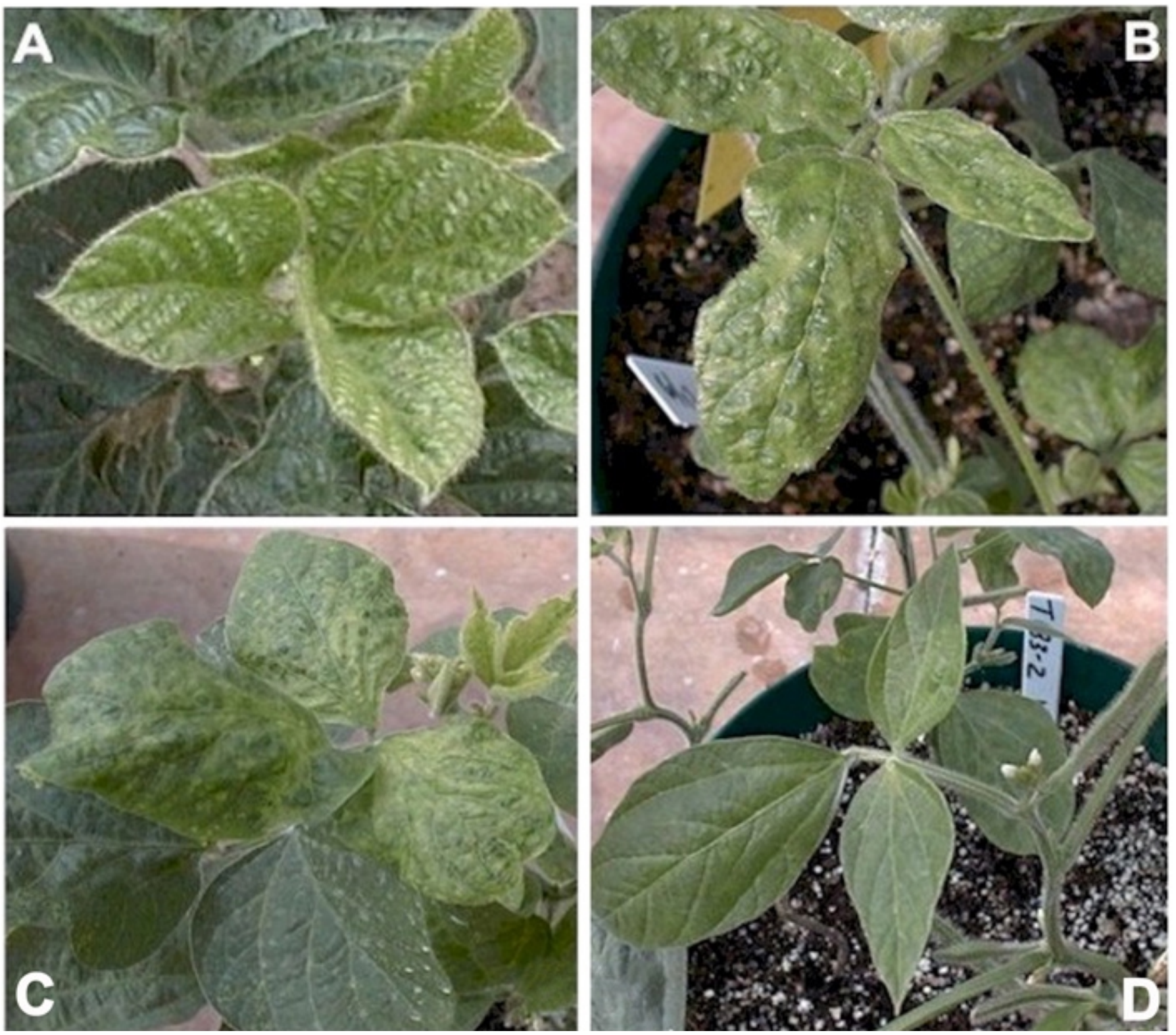

Fig. 8. Symptom development on transgenic and control soybean plants inoculated with Bean pod mottle virus (BPMV). A to D, Symptoms observed on the nontransformed wild-type 'Jack' soybean and the $\mathrm{T}_{2}$ progeny of lines 200-1 (plant 200-1-1), 183-1 (plant 183-1-2), and 183-2 (plant 183-2-1) are shown, respectively. The plants were mechanically inoculated with a severe strain (Hopkins) of BPMV and were monitored for symptom development for 3 weeks postinoculation. Chlorotic/necrotic symptoms appeared on the inoculated leaves of the susceptible control plants 4 to 5 days after inoculation, and systemic symptoms of severe mottling, leaf distortion, and blistering were observed 1 to 2 weeks. Progeny of line 183-2 showed little or no symptoms throughout the duration of the experiment, including the flowering and pod development stages. The youngest fully expanded leaves 5 weeks postinoculation were photographed. 
Western blot analysis of total soluble proteins from leaves of $\mathrm{T}_{0}$ transgenic plants $137,139,157,183$, and 186 showed a high level of expression of the 63-kDa pCP (Fig. 7, arrow). As expected, the $63-\mathrm{kDa}$ pCP was not detected in transgenic plant 200. It has previously been shown that the $\mathrm{pCP}$, produced in transgenic plants transformed with the $\mathrm{pCP}$ gene, neither undergoes proteolytic processing to the large (L) and small (S) capsid protein subunits (41 and $22 \mathrm{kDa}$ in size, respectively) nor assemble into viruslike particles (28). The virion $\mathrm{L}$ and $\mathrm{S}$ capsid proteins are shown in Figure 6, lane CP. The expression levels of the 63-kDa pCP were high in both young and mature leaves, and were estimated by ELISA to be as high as $0.02 \%$ of the total soluble protein in leaves from $\mathrm{T}_{0}$ transgenic plants 137, 139, 157, 183, and 186.

Resistance to BPMV in transgenic plants. Primary transformants $137,139,157,183,186$, and 200 were tested for resistance to the KY-G7 strain of BPMV by the detached leaf assay. When the detached leaves were tested by ELISA 7 days after inoculation, all transgenic leaves, with the exception of T-200, showed some resistance to BPMV infection, demonstrated by the lower levels of BPMV accumulation compared with the nontransformed control 'Jack' (Table 1). Because the T-200 plant lacks the BPMVpCP gene, its ELISA value was similar to the nontransgenic wildtype cv. Jack (Table 1). Virus movement from the BPMV-inoculated leaflets (two of the three leaflets of the trifoliolate detached leaf) to the mock-inoculated third leaflet was negligible as clearly shown by ELISA of the nontransformed control or vector-transformed plants (Table 1). Thus, the higher ELISA values for the mock-inoculated transgenic plants compared with the nontransgenic ones are due to the expression of the pCP gene.

The reactions of the progeny of lines 183-1 and 183-2 to rub-inoculation with a purified preparation of the severe strain Hopkins of BPMV are shown in Table 2 and Figure 8. The progeny of line 183-1 developed symptoms, but plant 183-1-2 was moderately resistant (based on level of BPMV accumulation) compared with the progeny of line 200-1 and nontransformed controls (Table 2). The susceptible plant 183-1-1, which did not inherit the pCP gene (Fig. 3C, lane 183-1-1), accumulated BPMV to a level comparable to that of the nontransgenic lines (Table 2). As stated earlier, line 183-1 is hemizygous and its progeny are predicted to segregate with respect to the transgene. Thus far, all progeny of homozygous line 183-2 analyzed to date were resistant, because they showed little or no symptoms throughout the duration of the experiment, including flowering and pod development stages.

TABLE 3. Double antibody sandwich, enzyme-linked immunosorbent assay (ELISA) of $\mathrm{T}_{2}$ transgenic plants on which viruliferous bean leaf beetles were allowed to feed for $72 \mathrm{~h}^{\mathrm{a}}$

\begin{tabular}{lcc}
\hline & \multicolumn{2}{c}{ ELISA values $\left(A_{405 \mathrm{~nm}}\right)^{\mathrm{c}}$} \\
\cline { 2 - 3 } $\begin{array}{l}\text { Plant number } \\
(+/- \text { pCP gene })^{\mathrm{b}}\end{array}$ & Upper leaves & $\begin{array}{c}\text { Lower leaves with } \\
\text { visible feeding sites }\end{array}$ \\
\hline $183-1-10(-)$ & $>2.00$ & 1.838 \\
$183-1-20(+)$ & 0.119 & 0.208 \\
$183-1-30(+)$ & 0.149 & 0.236 \\
$183-1-40(+)$ & 0.155 & 0.964 \\
$183-2-10(+)$ & 0.121 & 1.374 \\
$183-2-11(+)$ & 0.435 & 0.603 \\
$183-2-12(+)$ & 0.467 & 1.036 \\
$183-2-13(+)$ & 0.664 & 1.403 \\
$183-2-14(+)$ & 0.215 & 1.027 \\
'Jack' $(-)$ & $>2.0$ & 1.911 \\
$200-1-3(-)$ & 1.978 & 1.140
\end{tabular}

${ }^{a}$ ELISA values for noninoculated transgenic plants were in the range of 0.1 to 0.3 . ELISA values for noninoculated controls ('Jack' and 200-1-3, nontransformed and vector-transformed controls, respectively) were in the range of 0.010 to 0.015 .

b $(-)$ or $(+)$ indicates plants lacking or containing the capsid polyprotein $(\mathrm{pCP})$ gene, respectively, as determined by Southern blot hybridization analysis.

c Values are averages for two replicates. Results obtained with leaf extract dilutions of 1:10,000 (wt/vol) are shown.
Likewise, there was little or no accumulation of BPMV detected by ELISA (Table 2). A total of six 183-2 $\mathrm{T}_{2}$ progeny plant, including the three plants presented in Table 2, were tested by rubinoculation with a purified virion preparation, and all plants were resistant, with a mean ELISA value of 0.150 (data not shown). The higher resistance of the $\mathrm{T}_{2}$ progeny of line 183-2 compared with that of 183-1 is probably due to the fact that it is homozygous for the transgene. The limited number of $T_{2}$ progeny tested in these experiments was due to the fact that only 22 and 25 seeds, respectively, were recovered from lines 183-1 and 183-2.

In experiments with viruliferous bean leaf beetles, ELISA testing of leaves with visible feeding activities indicated that 9 of 11 plants tested became infected (Table 3 ). The two progeny plants that did not become infected were derived from line 183-1 (183-1-20 and 183-1-30); their ELISA values for the inoculated leaves were higher than those of the mock-inoculated nontransgenic controls because they express the pCP gene. Inoculated leaves of transgenic plant 183-1-40, on the other hand, did become infected but, interestingly, this plant did not become systemically infected. The response of this plant to virus infection suggests that it is homozygous for the pCP gene (Table 3). The response of plant 183-1-10, which did not inherit the pCP gene, to virus infection is comparable to that of nontransformed or vector-transformed plants (Table 3). Thus, the response of the segregating progeny of line 183-1 to virus infection is consistent with the conclusion that it is hemizygous. The upper noninoculated leaves of progeny of the homozygous line 183-2 showed reduced or no symptoms and accumulated little or no BPMV, determined by ELISA (Table 3, compare ELISA values with those of mock-inoculated transgenic plants). The difference in virus accumulation in the $\mathrm{T}_{2}$ progeny of line 183-2 between rub-inoculation of virions (Table 2) compared with beetle inoculation (Table 3 ) may reflect different responses to the inoculation methods.

In summary, some of the transgenic soybean lines generated in this study exhibited resistance to systemic infection by BPMV. Progeny of the homozygous transgenic line 183-2 could provide valuable material for incorporation into commercial varieties. Because of the current outbreak of BPMV in the major soybeangrowing regions and the absence of natural resistance, there is a need to develop commercial cultivars with BPMV resistance.

\section{ACKNOWLEDGMENTS}

This research was primarily supported by grant 9213 from the United Soybean Board (USB) awarded to the laboratory of G. B. Collins. S. A. Ghabrial was supported in part by USB grant 8212 . This paper (00-06$159)$ is published with the approval of the Director of the Kentucky Agricultural Experiment Station. We thank C. Meurer and M. Hayes for technical support, K. McAllister for helpful discussions, and R. Stevens and A. Crume for greenhouse care and pod collection.

\section{LITERATURE CITED}

1. Anjos, R. J., Jarlfors, U., and Ghabrial, S. A. 1992. Soybean mosaic potyvirus enhances the titer of two comoviruses in dually infected soybean plants. Phytopathology 82:1022-1027.

2. Aragão, F. J. L., Sarokin, L., Vianna, G. R., and Rech, E. L. 2000. Selection of transgenic meristematic cells utilizing a herbicidal molecule results in the recovery of fertile transgenic soybean [Glycine $\max (\mathrm{L}$. Merril] plants at high frequency. Theor. Appl. Genet. 101:1-6.

3. Baulcombe, D. C. 1996. Mechanisms of pathogen-derived resistance to viruses in transgenic plants. Plant Cell 8:1833-1844.

4. Bendahmane, M., and Beachy, R. N. 1999. Control of tobamovirus infections via pathogen-derived resistance. Adv. Virus Res. 53:369-386.

5. Calvert, L. A., and Ghabrial, S. A. 1983. Enhancement by soybean mosaic virus of bean pod mottle virus titer in doubly infected soybean. Phytopathology 73:992-997.

6. Christou, P., Swain, W. F., Yang, N.-S., and McCabe, D. E. 1989. Inheritance and expression of foreign genes in transgenic soybean plants. Proc. Natl. Acad. Sci. USA 86:7500-7504.

7. Di, R., Hu, C.-C., and Ghabrial, S. A. 1999. Complete nucleotide 
sequence of bean pod mottle virus RNA1: Sequence comparisons and evolutionary relationships to other comoviruses. Virus Genes 18:129-137.

8. Di, R., Purcell, V., Collins, G. B., and Ghabrial, S. A. 1996. Production of transgenic soybean lines expressing the bean pod mottle virus coat protein precursor gene. Plant Cell Rep. 15:746-750.

9. Fehr, W. R., Caviness, C. E., Burmood, D. T., and Pennington, J. S. 1971. Stages of development descriptions for soybeans, Glycine max (L.) Merr. Crop Sci. 11:929-931.

10. Fitchen, J. H., and Beachy, R. N. 1993. Genetically engineered protection against viruses in transgenic plants. Annu. Rev. Microbiol. 47:739763.

11. Gamborg, O. L., Miller, R. A., and Ojima, K. 1968. Nutrient requirements of suspension cultures of soybean root cells. Exp. Cell Res. 50:150-158.

12. Gergerich, R. C., and Scott, H. A. 1996. Comoviruses: Transmission, Epidemiology, and Control. Pages 77-98 in: The Plant Viruses 5: Polyhedral Virions and Bipartite RNA Genomes. B. D. Harrison and A. F. Murant, eds. Plenum Press, New York.

13. Ghabrial, S. A., Hershman, D. E., Johnson, D. W., and Yan, D. 1990. Distribution of bean pod mottle virus in soybeans in Kentucky. Plant Dis. 74:132-134.

14. Ghabrial, S. A., and Schultz, F. J. 1983. Serological detection of bean pod mottle virus in bean leaf. Phytopathology 73:480-483.

15. Goldbach, R., Martelli, G. P., and Milne, R. G. 1995. Family Comoviridae. Pages 341-347 in: Virus Taxonomy. F. A. Murphy, C. M. Fauquet, D. H. L. Bishop, S. A. Ghabrial, A. W. Jarvis, G. P. Martelli, M. A. Mayo, and M. D. Summers, eds. Springer-Verlag, New York.

16. Hartman, G. L., Sinclair, J. B., and Rupe, J. C. 1999. Compendium of Soybean Diseases. 4th ed. The American Phytopathological Society, St. Paul, MN.

17. Jefferson, R. A. 1987. Assaying chimeric genes in plants: The GUS gene fusion system. Plant Mol. Biol. Rep. 5:387-405.

18. Laemmli, U. K. 1970. Cleavage of structural proteins during the assembly of the head of bacteriophage T4. Nature 227:680-685.

19. Lomonossoff, G. P. 1994. Comoviruses. Pages 249-254 in: Encyclopedia of Virology. Vol. 3. R. G. Webster and A. Granoff, eds. Academic Press, New York.

20. Lomonossoff, G. P. 1995. Pathogen-derived resistance to plant viruses. Annu. Rev. Phytopathol. 33:323-343.

21. MacFarlane, S. A., Shanks, M., Davies, J. W., Zlotnick, A., and Lomonossoff, G. P. 1991. Analysis of the nucleotide sequence of bean pod mottle virus middle component RNA. Virology 183:405-409.

22. Maiti, I. B., Gowda, S., Kiernan, J., Ghosh, S. K., and Shepherd, R. J. 1997. Promoter/leader deletion analysis and plant expression vectors with the figwort mosaic virus (FMV) full-length transcript (FLt) promoter containing single or double enhancer domains. Transgenic Res. 6:143-156.

23. Maughan, P. J., Philip, R., Cho, M.-J., Widholm, J. M., and Vodkin, L. O. 1999. Biolistic transformation, expression and inheritance of bovine $\beta$-casein in soybean (Glycine max). In Vitro Cell Dev. Biol. 35:334-349.

24. McCabe, D. E., Swain, W. F., Martinell, B. J., and Christou, P. 1988. Stable transformation of soybean (Glycine max) by particle acceleration. Bio-Technology 6:923-926.

25. Meurer, C. A., Dinkins, R. D., and Collins, G. B. 1998. Factors affecting soybean cotyledonary node transformation. Plant Cell Rep. 18:180-186.

26. Miller, E. D., and Hemenway, C. 1998. History of coat protein-mediated protection. Methods Mol. Biol. 81:25-38.
27. Murashige, T., and Skoog, F. 1962. A revised medium for rapid growth and bioassays with tobacco tissue cultures. Physiol. Plant 15:473-497.

28. Nida, D. L., Anjos, J. R., Lomonossoff, G. P., and Ghabrial, S. A. 1992. Expression of cowpea mosaic virus coat protein precursor in transgenic tobacco plants. J. Gen. Virol. 73:157-163.

29. Pang, S.-Z., Jan, F.-J., Tricoli, D. M., Russel, P. F., Carney, K. J., Hu, J. S., Fuchs, M., Quemada, H. D., and Gonsalves, D. 2000. Resistance to Squash mosaic comovirus in transgenic squash plants expressing its coat protein genes. Mol. Breed. 6:87-93.

30. Parrott, W. A., All, J. N., Adang, M. J., Bailey, M. A., Boerma, H. R., and Stewart, C. N., Jr. 1994. Recovery and evaluation of soybean [Glycine $\max$ (L.) Merr.] plants transgenic for a Bacillus thuringiensis var. kurstaki insecticidal gene. In Vitro Cell Dev. Biol. 30:144-149.

31. Ponappa, T., Brzozowski, A. E., and Finer, J. J. 1999. Transient expression and stable transformation of soybean using jellyfish green fluorescent protein. Plant Cell Rep. 19:6-12.

32. Ross, J. P. 1963. Transmission of bean pod mottle virus in soybean by beetles. Plant Dis. Rep. 47:1044-1050.

33. Ross, J. P. 1968. Effect of single and double infections of soybean mosaic and bean pod mottle viruses on soybean yield and seed characters. Plant Dis. Rep. 52:344-348.

34. Ross, J. P., and Butler, A. K. 1985. Distribution of bean pod mottle virus in soybeans in North Carolina. Plant Dis. 69:101-103.

35. Samoylov, V. M., Tucker, D. M., and Parrott, W. A. 1998. A liquid medium-based protocol for rapid regeneration from embryogenic soybean cultures. Plant Cell Rep. 18:49-54

36. Sanford, J. C., and Johnston, S. A. 1985. The concept of parasite-derived resistance-deriving resistance genes from the parasite's own genome. J. Theor. Biol. 113:395-405.

37. Santarem, E. R., Pelissier, B., and Finer, J. J. 1997. Effect of explant orientation, $\mathrm{pH}$, solidifying agent and wounding on initiation of soybean somatic embryos. In Vitro Cell Dev. Biol. 33:13-19.

38. Schmitthenner, A. F., and Kmetz, K. 1980. Role of Phomopsis spp. in the soybean seed rot problem. Pages 355-366 in: Proc. World Soybean Res. Conf., 2nd.

39. Skotland, C. B. 1958. Bean pod mottle virus of soybeans. Plant Dis. Rep. 42:1155-1156.

40. Stuckey, R. E., Ghabrial, S. A., and Reicosky, D. A. 1982. Increased incidence of Phomopsis spp. in seeds from soybeans infected with bean pod mottle virus. Plant Dis. 66:826-829.

41. Torisky, R., Fellers, J. P., and Collins, G. B. 1996. A focusing device for tissue transformation with the DuPont/BioRad PDS1000 helium microprojectile system. Plant Mol. Biol. Rep. 14:124-133.

42. Trick, H. N., Dinkins, R. D., Santarem, E. R., Di, R., Samoylov, V., Meurer, C. A., Walker, D. R., Parrott, W. A., Finer, J. J., and Collins, G. B. 1997. Recent advances in soybean transformation. Plant Tissue Cult. Biotechnol. 3:9-26.

43. Walker, D. R., and Parrott, W. A. 2000. Normalizing soybean somatic embryo development in liquid medium. Plant Cell Tissue Organ Cult. 64:55-62.

44. Yan, B., Reddy, M. S. S., Collins, G. B., and Dinkins, R. D. 2000. Agrobacterium tumefaciens-mediated transformation of soybean [Glycine $\max ($ L.) Merrill] immature zygotic cotyledon explants. Plant Cell Rep. 19:1090-1097.

45. Zhang, Z., Xing, A., Staswick, P., and Clemente, T. E. 1999. The use of glufosinate as a selective agent in Agrobacterium-mediated transformation of soybean. Plant Cell Tissue Organ Cult. 56:37-46.

\section{Erratum}

\section{Vol. 91, No. 9, 2001}

In the manuscript entitled "Resistance to Bean pod mottle virus in Transgenic Soybean Lines Expressing the Capsid Polyprotein" by M. S. S. Reddy, S. A. Ghabrial, C. T. Redmond, R. D. Dinkins, and G. B. Collins (Phytopathology 91:831-838), the first column of Table 2 incorrectly reports that progeny 200-1-1 and 200-1-2 contain the capsid polyprotein gene. Progeny 200-1-1 and 200-1-2 do not contain the capsid polyprotein gene. 